\title{
High Spin Ground States in Matryoshka Actinide Nanoclusters: A Computational Study
}

DOI:

10.1002/chem.201705196

\section{Document Version}

Accepted author manuscript

Link to publication record in Manchester Research Explorer

\section{Citation for published version (APA):}

Hu, H-S., \& Kaltsoyannis, N. (2018). High Spin Ground States in Matryoshka Actinide Nanoclusters: A

Computational Study. Chemistry: A European Journal , 24, 347-350. https://doi.org/10.1002/chem.201705196

\section{Published in:}

Chemistry: A European Journal

\section{Citing this paper}

Please note that where the full-text provided on Manchester Research Explorer is the Author Accepted Manuscript or Proof version this may differ from the final Published version. If citing, it is advised that you check and use the publisher's definitive version.

\section{General rights}

Copyright and moral rights for the publications made accessible in the Research Explorer are retained by the authors and/or other copyright owners and it is a condition of accessing publications that users recognise and abide by the legal requirements associated with these rights.

\section{Takedown policy}

If you believe that this document breaches copyright please refer to the University of Manchester's Takedown Procedures [http://man.ac.uk/04Y6Bo] or contact uml.scholarlycommunications@manchester.ac.uk providing relevant details, so we can investigate your claim.

\section{OPEN ACCESS}




\title{
High Spin Ground States in Matryoshka Actinide Nanoclusters: A Computational Study
}

\author{
Han-Shi Hu and Nikolas Kaltsoyannis*
}

\begin{abstract}
Inspired by the experimentally synthesized $\mathrm{Na}_{12} @\left[\left(\mathrm{UO}_{2}\right)\left(\mathrm{O}_{2}\right)_{1.5}\right]_{20}{ }^{8-}$ ("Na ${ }_{12} @ \mathrm{U}_{20}$ ") cluster, we have explored computationally the substitution of the Na cations by many other metals. 6 other $\mathrm{M}_{12} @ \mathrm{U}_{20}$ systems are found to be stable $\left(\mathrm{M}=\mathrm{K}^{+}\right.$, $\left.\mathrm{Rb}^{+}, \mathrm{Cs}^{+}, \mathrm{Ag}^{+}, \mathrm{Mg}^{2+}, \mathrm{Fe}^{2+}\right)$. For 3 of these $\left(\mathrm{Mg}^{2+}, \mathrm{Ag}^{+}\right.$and $\left.\mathrm{Na}^{+}\right)$, the cluster can support a group 16 dianion at its centre, forming a new type of Matryoshka ("Russian Doll") actinide nanocluster $\mathrm{E} @ \mathrm{M}_{12} @ \mathrm{U}_{20}\left(\mathrm{E}=\mathrm{S}^{2-}, \mathrm{Se}^{2-}, \mathrm{Te}^{2-}\right.$ and $\left.\mathrm{Po}^{2-}\right)$. These systems have 3-shell, onion-like geometries with nearly perfect $I_{\mathrm{h}}$ symmetry. Seeking to create clusters with very high-spin ground states, we have replaced $\mathrm{M}$ by $\mathrm{Mn}^{2+}$ and $\mathrm{U}_{20}$ by $\mathrm{Np}_{20}$ and $\mathrm{Pu}_{20}$, generating clusters with maximum possible $S$ values of $80 / 2$ and $100 / 2$ respectively. Only in the presence of a central $\mathrm{S}^{2-}$, however, are these electronic configurations the most stable; the novel Matryoshka Pu nanocluster $\mathrm{S} @ \mathrm{Mn}_{12} @ \mathrm{Pu}_{20}$ is predicted to have the highest ground state spin yet reported for a molecular cluster.
\end{abstract}

The search for molecules with very high spin ground states remains an active area of research, in part motivated by the burgeoning field of single molecule magnetism and its potential application in information storage, spintronics and quantum computing. ${ }^{1,2}$ Many high-spin molecules have been reported following the discovery of the $S=20 / 2 \mathrm{Mn}_{12}$ singlemolecule magnet in 1993 . $^{3}$ Two years later, an $\mathrm{Fe}_{19}$ molecular cluster with $S=33 / 2$ was discovered, and held the spin record ${ }^{4}$ until 2000, when two heteronuclear clusters $M_{9} M_{6}$ $(\mathrm{M}=\mathrm{Mo}$ and $\mathrm{W})$ with $S=39 / 2$ were characterized. ${ }^{5}$ Four years later the bar was further raised when an $\mathrm{Mn}_{25}$ cluster with $S=51 / 2$ was reported. ${ }^{6}$ Since then, $S=83 / 2$ has been established (by mixing high-spin $\mathrm{Mn}$ (II) and $\mathrm{Mn}$ (III) in large clusters), ${ }^{7}$ and the largest $S$ value for a molecular cluster known to date is 90/2, from an $\mathrm{Fe}_{45}$ giant-spin nanocluster. ${ }^{8}$ In this contribution, we use computational quantum chemistry to explore the geometric and electronic structures of actinide nanoclusters. We report the first multi-shell, Matryoshka ("Russian Doll") actinide-transition metal complexes and, by judicious choice of $5 f$ and $3 d$ elements, establish a new record high-spin ground state for a molecular cluster.

The linear uranyl ion $\mathrm{OUO}^{2+}$ is ubiquitous in uranium chemistry and, over the last few years, a wide range of selfassembled uranyl peroxide nanoclusters has been

${ }^{\star}{ }^{*} \quad$ Dr. H. S. Hu, Prof. N. Kaltsoyannis

School of Chemistry

The University of Manchester

Oxford Road, Manchester M13 9PL, UK

E-mail: nikolas.kaltsoyannis@manchester.ac.uk

Supporting information for this article is given via a link at the end of the document. synthesized, including more than forty with closed cages constructed from up to 60 uranyl building blocks. 9,10,11 These have highly symmetric fullerene topologies, and can encapsulate $s$ block cations, raising intriguing possibilities for the design of actinide materials at the nanocluster scale. ${ }^{12}$ Outside of the laboratory, these uranyl-based nanoclusters are potentially of environmental significance, as they could enhance the corrosion of spent nuclear fuel, play a role in the migration of uranium in the natural environment, and be key intermediates in the formation of uranyl containing minerals from aqueous uranyl compounds. ${ }^{13,14}$ Of these nanoclusters, $\mathrm{Na}_{12} @\left[\left(\mathrm{UO}_{2}\right)\left(\mathrm{O}_{2}\right)_{1.5}\right]_{20}{ }^{8-},{ }^{2}$ denoted $\mathrm{Na}_{12} @ \mathrm{U}_{20}$ herein, is the smallest fullerene cluster; it contains twelve pentagons, each built from five $\mathrm{UO}_{2}{ }^{2+}$ and five $\mathrm{O}_{2}{ }^{2-}$ ligands, and has near $I_{\mathrm{h}}$ symmetry. It can be considered to consist of two shells, an outer $\left[\left(\mathrm{UO}_{2}{ }^{2+}\right)_{20}\left(\mathrm{O}_{2}{ }^{2-}\right)_{30}\right]^{20-}$ shell $\left(\mathrm{U}_{20}\right.$ for short $)$ and an inner $\mathrm{Na}_{12}{ }^{12+}$ shell $\left(\mathrm{Na}_{12}\right)$ encapsulated inside $\mathrm{U}_{20}$, as shown in Figure 1. Each uranyl ion is coordinated by three $\mathrm{O}_{2}{ }^{2-}$ ligands, and each peroxide ligand is shared by two uranyl ions. Herein, we use density functional theory (DFT) to design and explore novel nanoclusters based on $\mathrm{Na}_{12} @ \mathrm{U}_{20}$ via modifications of both the inner and outer shells. Details of our computational methodology are given in the Supporting Information.

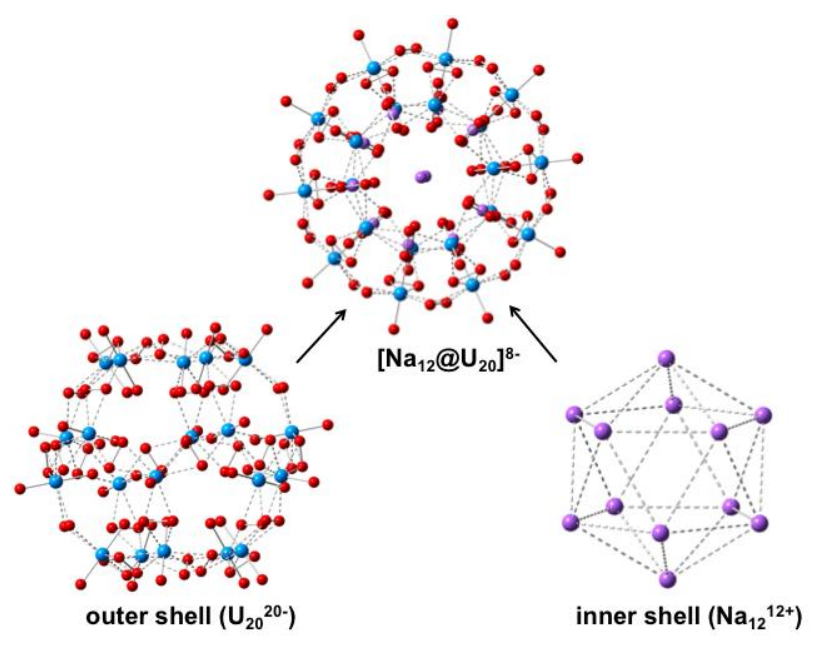

Figure 1. Ball and stick representation of $\left[\mathrm{Na}_{12} @ \mathrm{U}_{20}\right]^{8-}$ and its breakdown into outer shell $\mathrm{U}_{20}{ }^{20-}$ and inner shell $\mathrm{Na}_{12}{ }^{12+}$ fragments. Uranium atoms in blue, oxygen atoms in red and sodium atoms in purple. 
Table 1. Selected angles $\left(^{\circ}\right)$ and bond lengths $(\AA)$ from the DFT-optimized $(\mathrm{PBE} / \mathrm{TZP})$ structures of $\mathrm{M}_{12} @ \mathrm{U}_{20}\left(\mathrm{M}^{2}=\mathrm{Fe}^{2+}, \mathrm{Mg}^{2+}, \mathrm{Ag}^{+}, \mathrm{Na}^{+}, \mathrm{K}^{+}, \mathrm{Rb}^{+}\right.$and $\left.\mathrm{Cs}^{+}\right)$.

\begin{tabular}{|c|c|c|c|c|c|c|c|}
\hline & $\mathrm{M}=\mathrm{Fe}^{2+}$ & $\mathrm{M}=\mathrm{Mg}^{2+}$ & $\mathrm{M}=\mathrm{Ag}^{+}$ & $\mathrm{M}=\mathrm{Na}^{+}$ & $\mathrm{M}=\mathrm{K}^{+}$ & $\mathrm{M}=\mathrm{Rb}^{+}$ & $\mathrm{M}=\mathrm{Cs}^{+}$ \\
\hline$\angle \mathrm{U}-\mathrm{O}-\mathrm{O}-\mathrm{U}$ & 142.75 & 145.01 & 141.45 & 143.75 & 146.58 & 147.13 & 147.61 \\
\hline$\angle \mathrm{O}=\mathrm{U}=\mathrm{O}$ & 179.95 & 179.97 & 179.97 & 179.98 & 179.88 & 179.89 & 179.92 \\
\hline $\mathrm{O}_{\text {out }}=\mathrm{U}$ & 1.79 & 1.78 & 1.84 & 1.84 & 1.84 & 1.83 & 1.83 \\
\hline$U=O_{\text {in }}$ & 2.16 & 2.11 & 1.90 & 1.87 & 1.85 & 1.84 & 1.83 \\
\hline O-O (peroxo) & 1.47 & 1.47 & 1.47 & 1.47 & 1.47 & 1.47 & 1.46 \\
\hline U-Operoxo & 2.30 & 2.31 & 2.38 & 2.38 & 2.42 & 2.43 & 2.47 \\
\hline M-Mnearest & 3.01 & 3.56 & 3.72 & 4.12 & 4.56 & 4.73 & 4.99 \\
\hline $\mathrm{O}_{\text {in }}-\mathrm{M}$ & 2.18 & 2.30 & 2.51 & 2.60 & 2.78 & 2.85 & 2.98 \\
\hline
\end{tabular}

Table 2. Selected angles $\left({ }^{\circ}\right)$ and bond lengths $(\AA)$ from the DFT-optimized $(P B E / T Z P)$ structures of $E @ M_{12} @ U_{20}\left(M=M g^{2+}, A^{+}\right.$and $N a^{+} ; E=S, S e, T e$ and $\left.P o\right)$.

\begin{tabular}{|c|c|c|c|c|c|c|c|c|c|c|c|c|}
\hline & \multicolumn{4}{|c|}{$\mathrm{M}=\mathrm{Mg}^{2+}$} & \multicolumn{4}{|c|}{$\mathrm{M}=\mathrm{Ag}^{+}$} & \multicolumn{4}{|c|}{$\mathrm{M}=\mathrm{Na}^{+}$} \\
\hline & $E=S$ & $\mathrm{E}=\mathrm{Se}$ & $\mathrm{E}=\mathrm{Te}$ & $E=P o$ & $E=S$ & $\mathrm{E}=\mathrm{Se}$ & $\mathrm{E}=\mathrm{Te}$ & $\mathrm{E}=\mathrm{Po}$ & $E=S$ & $\mathrm{E}=\mathrm{Se}$ & $\mathrm{E}=\mathrm{Te}$ & $E=P o$ \\
\hline$\angle \mathrm{U}-\mathrm{O}-\mathrm{O}-\mathrm{U}$ & 142.56 & 142.82 & 143.70 & 143.45 & 141.39 & 141.84 & 141.84 & 142.78 & 141.33 & 142.17 & 142.51 & 142.70 \\
\hline$\angle \mathrm{O}=\mathrm{U}=\mathrm{O}$ & 179.99 & 179.99 & 179.95 & 179.87 & 179.91 & 179.84 & 179.84 & 179.88 & 179.98 & 179.97 & 179.94 & 179.99 \\
\hline $\mathrm{O}_{\text {out }}=\mathrm{U}$ & 1.79 & 1.79 & 1.79 & 1.79 & 1.85 & 1.85 & 1.85 & 1.85 & 1.85 & 1.85 & 1.85 & 1.85 \\
\hline$U=O_{\text {in }}$ & 2.09 & 2.09 & 2.09 & 2.08 & 1.88 & 1.88 & 1.88 & 1.88 & 1.87 & 1.87 & 1.86 & 1.86 \\
\hline O-O (peroxo) & 1.47 & 1.47 & 1.47 & 1.47 & 1.47 & 1.47 & 1.47 & 1.47 & 1.47 & 1.47 & 1.47 & 1.47 \\
\hline U-O peroxo & 2.31 & 2.31 & 2.31 & 2.31 & 2.39 & 2.39 & 2.39 & 2.39 & 2.39 & 2.39 & 2.39 & 2.39 \\
\hline$M-M_{\text {nearest }}$ & 3.33 & 3.36 & 3.40 & 3.41 & 3.16 & 3.21 & 3.18 & 3.28 & 3.48 & 3.50 & 3.61 & 3.64 \\
\hline$O_{\text {in }}-M$ & 2.26 & 2.27 & 2.27 & 2.29 & 2.53 & 2.54 & 2.53 & 2.54 & 2.53 & 2.52 & 2.55 & 2.54 \\
\hline E-M & 3.17 & 3.18 & 3.22 & 3.24 & 2.99 & 3.03 & 3.03 & 3.14 & 3.33 & 3.34 & 3.45 & 3.45 \\
\hline$E-O_{\text {in }}$ & 3.72 & 3.73 & 3.73 & 3.75 & 4.16 & 4.17 & 4.14 & 4.21 & 4.16 & 4.16 & 4.18 & 4.19 \\
\hline $\mathrm{M}-\mathrm{M}_{\max }$ & 6.34 & 6.37 & 6.45 & 6.48 & 5.98 & 6.06 & 6.13 & 6.27 & 6.66 & 6.69 & 6.80 & 6.92 \\
\hline $\mathrm{U}-\mathrm{U}_{\max }$ & 11.59 & 11.60 & 11.61 & 11.65 & 12.04 & 12.10 & 12.10 & 12.05 & 12.05 & 12.06 & 12.08 & 12.10 \\
\hline
\end{tabular}

Table 1 collects key structural data for $\mathrm{Na}_{12} @ \mathrm{U}_{20}$. The peroxide O-O bond length of c. $1.47 \AA$ is significantly shorter in the $\mathrm{U}_{20}$ cage than in the naked anion (c. $1.68 \AA$ ), due to transfer of anti-bonding electrons from $\mathrm{O}_{2}{ }^{2-}$ to the vacant orbitals of $\mathrm{UO}_{2}{ }^{2+}$. The significantly bent dihedral angle $\angle \mathrm{U}-\mathrm{O}-$ O-U plays an important role in forming the ball-like $\mathrm{U}_{20}$ cage. $^{15}$ Due to interactions with the inner $\mathrm{Na}_{12}$ shell, the inward $\mathrm{U}=\mathrm{O}$ bond length $\left(\mathrm{U}=\mathrm{O}_{\text {in }}\right)$ is longer than the outward one $\left(\mathrm{O}_{\text {out }}=\mathrm{U}\right)$, 1.87 vs $1.84 \AA$.

With $\mathrm{Na}_{12} @ \mathrm{U}_{20}$ in hand, we searched for other cation shells that can be stabilized inside the $U_{20}$ cage. We scanned all the alkali, alkaline-earth and divalent $3 d$-metal cations, as well as $\mathrm{Ag}^{+}$as its radius is close to that of $\mathrm{Na}^{+}$. True minimum structures were obtained for $\mathrm{M}_{12} @ \mathrm{U}_{20}$ with $\mathrm{M}=\mathrm{K}^{+}, \mathrm{Rb}^{+}, \mathrm{Cs}^{+}$, $\mathrm{Ag}^{+}, \mathrm{Mg}^{2+}$ and $\mathrm{Fe}^{2+}$. These new nanoclusters retain the same near $I_{\mathrm{h}}$ topology of the $\mathrm{Na}$ system; the optimized geometric parameters are collected in Table 1. Varying the cation does not affect the $\angle \mathrm{U}-\mathrm{O}-\mathrm{O}-\mathrm{U}$ dihedral angles very much - all are within $2.50^{\circ}$ of one another. The uranyl units are all essentially linear, and the $\mathrm{U}-\mathrm{O}$ distances in the systems with monocationic $M_{12}$ cages are little perturbed from those of regular uranyl $\mathrm{l}^{\mathrm{VI}}$ complexes. By contrast, the substantially stronger electrostatics of the $\mathrm{Fe}^{2+}$ - and $\mathrm{Mg}^{2+}$-based $\mathrm{M}_{12}$ cages result in appreciably lengthened $\mathrm{U}=\mathrm{O}_{\text {in. }}$ Interestingly, the formally closed-shell $\mathrm{O}_{\text {in }}$ atoms in these systems have spin densities of just over 0.2 , suggestive of incipient two-centre radical bonding characteristics.

The $\mathrm{Fe}_{12}$ cage has the smallest "diameter" (5.67 $\AA$, taken as the farthest distance between $\mathrm{Fe}^{2+}$ ions) consistent with it having the smallest cation radius and highest positive charge. By contrast, the $\mathrm{Cs}_{12}$ cage has the largest diameter (9.51 $\AA$ ), due to $\mathrm{Cs}^{+}$being the largest monovalent ion considered. The diameter of the outer shell $U_{20}$ cage (taken as the largest $U-U$ distance) varies relatively little as a function of the inner $M_{12}$ cage, ranging from 11.63 to $12.68 \AA$ between $\mathrm{M}=\mathrm{Fe}^{2+}$ and $\mathrm{M}$ $=\mathrm{Cs}^{+}$. The $\mathrm{O}_{\text {in }}-\mathrm{O}_{\text {in }}$ distances, the largest distances between inward-pointing uranyl oxygens, have a larger range, 7.34 to $9.02 \AA$. Figure 2 collects these diameter data; the inner $M_{12}$ shell changes much the most of the three datasets, showing the versatility of the $U_{20}$ cage for the encapsulation of cation shells.

All of the above $\mathrm{M}_{12} @ \mathrm{U}_{20}$ clusters have closed-shell electronic structures except $\mathrm{Fe}_{12} @ \mathrm{U}_{20}$. This arises from the four unpaired $3 d$ electrons on each $\mathrm{Fe}^{2+}$ centre. These are coupled ferromagnetically in our calculations, giving a system with $S=48 / 2$. We tried to increase this still further by encapsulating a cage of $12 \mathrm{Mn}^{2+}$ ions (each of which has five unpaired $3 d$ electrons) but it did not prove possible to locate a true minimum structure for $\mathrm{Mn}_{12} @ \mathrm{U}_{20}$.

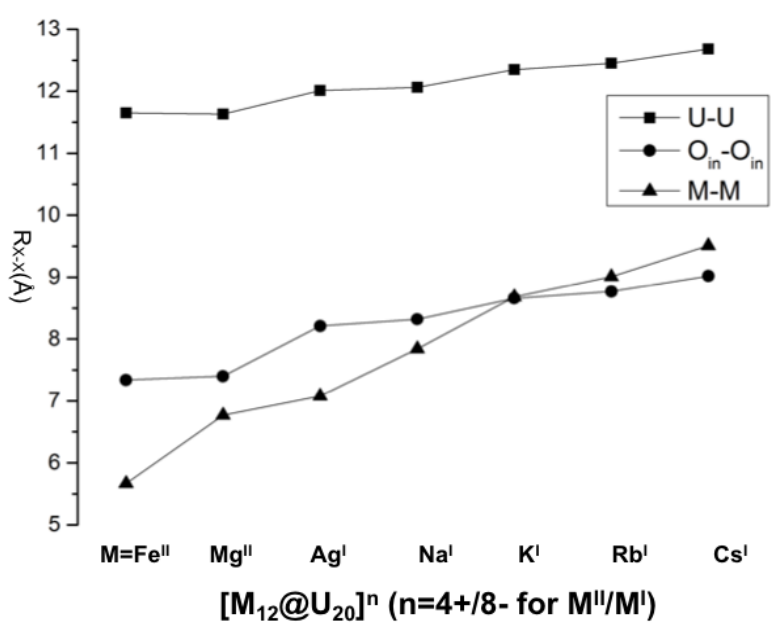

Figure 2. $X-X$ diameters $\left(X=U, O_{\text {in }}, M\right)$ of $M_{12} @ U_{20}$ based on DFT optimization. 
Matryoshka ("Russian Doll") nanoclusters have icosahedral structures and general formula $\mathrm{E} @ \mathrm{M}_{12} @ \mathrm{E}_{20}$ (Figure 3 ) where $E$ is a main group element and $M$ is a metal atom. ${ }^{16}, 17,18,19$ We were interested to see if we could generate analogues of such systems using our $\mathrm{M}_{12} @ \mathrm{U}_{20}$ clusters, thereby forming the first actinide Matryoshka clusters, in which uranyl ions replace main group atoms as the basic building block of the outer shell. We therefore placed a group 16 dianion, $\mathrm{O}^{2-}, \mathrm{S}^{2-}, \mathrm{Se}^{2-}, \mathrm{Te}^{2-}$ or $\mathrm{Po}^{2-}$ into the centre of each of our seven $\mathrm{M}_{12} @ \mathrm{U}_{20}$ clusters. Of these, only $\mathrm{Mg}_{12} @ \mathrm{U}_{20}, \mathrm{Ag}_{12} @ \mathrm{U}_{20}$ and $\mathrm{Na}_{12} @ \mathrm{U}_{20}$ yielded optimized true minimum structures, and then only with the heavier group 16 anions; $\mathrm{O}^{2-}$ did not stay in the centre of the cluster, but migrated to sit over one of the $M_{3}$ triangles of the $M_{12}$ cages. It therefore appears that the stability of the $\mathrm{E} @ \mathrm{M}_{12} @ \mathrm{U}_{20}$ motif is limited to the heavier group 16 dianions in conjunction with $\mathrm{M}_{12}$ cages with a rather narrow range of diameters; $\mathrm{Mg}^{2+}, \mathrm{Ag}^{+}$ and $\mathrm{Na}^{+}$yield cages with diameters from 6.77 to $7.84 \AA$. Key structural data for our new actinide Matryoshka nanoclusters are collected in Table 2, and a summary of all of our $\mathrm{U}_{20}$-based systems is given in Scheme 1. Table 2 shows that changing the central $E^{2-}$ has only a minor effect on the size of the $\mathrm{M}_{12}$ and $\mathrm{U}_{20}$ cages.

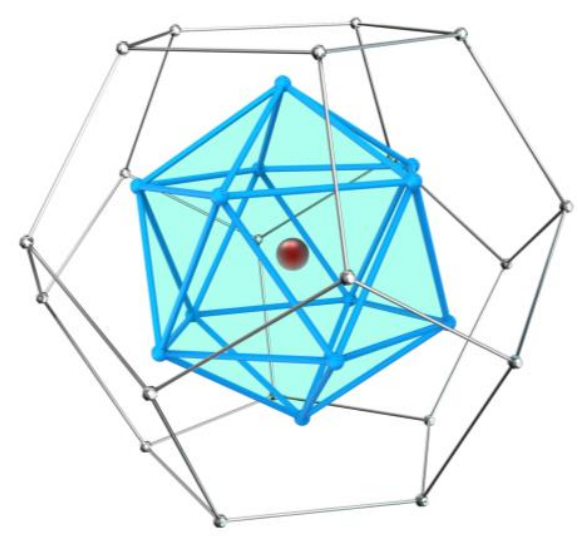

Figure 3. Schematic representation of a Matryoshka cluster with a threelayer Russian doll structure and general formula $E @ M_{12} @ E_{20}(E$ is a maingroup element and $\mathrm{M}$ is a metal atom). The red in the centre represents $\mathrm{E}$, the blue cage represents the inner $M_{12}$ shell and the outer grey cage represents the $E_{20}$.

The uranyl ion contains $\mathrm{U}(\mathrm{VI})$ and hence has no unpaired electrons. Replacing uranyl by its heavier congenors
neptunylVI $\left(\mathrm{NpO}_{2}{ }^{2+}\right)$ or plutonyl $\mathrm{Vl}^{\mathrm{VI}}\left(\mathrm{PuO}_{2}{ }^{2+}\right)$ will introduce, respectively, one and two unpaired $5 f$ electrons per actinyl unit to the nanoclusters. In searching for systems with very high-spin ground states, we tried encapsulating cages of twelve $\mathrm{Mn}^{2+}$ ions in $\mathrm{Np}_{20}$ and $\mathrm{Pu}_{20}$ cages. Pleasingly, although $\mathrm{Mn}_{12}$ is not stable in $\mathrm{U}_{20}$ (vide supra), it is so inside the heavier actinyl cages. Table 3 collects the relative energies of the highest spin states of $\mathrm{Mn}_{12} @ \mathrm{~Np}_{20}$ and $\mathrm{Mn}_{12} @ \mathrm{Pu}_{20}$, computed at various levels of DFT and basis set. Unfortunately, the highest possible spin state $(S=80 / 2$ for the $\mathrm{Np}_{20}$ cluster $\left(S=60 / 2\right.$ from the $123 \mathrm{~d}^{5} \mathrm{Mn}^{2+}$ ions $+S=20 / 2$ from the $205 f^{1} \mathrm{NpO}_{2}{ }^{2+}$ ions) and 100/2 for $\mathrm{Pu}_{20}$ (as for the $\mathrm{Np}_{20}$ system but with two $5 f$ electrons per actinyl)) is not the most stable, with lower spin, non-Aufbau configurations being much more energetically preferred. Undeterred, we moved on to consider neptunyl and plutonyl analogues of our new Matryoshka nanoclusters. The only group 16 dianion which is stable in both $\mathrm{E} @ \mathrm{Mn}_{12} @ \mathrm{~Np}_{20}$ and $\mathrm{E} @ \mathrm{Mn}_{12} @ \mathrm{Pu}_{20}$ is $\mathrm{S}^{2-}$. The heavier chalcogen ions are stable in the neptunium system but not in $\mathrm{Pu}_{20}$. Remarkably, the presence of the closed-shell $\mathrm{S}^{2-}$ at the centre of the clusters significantly modifies the energetic ordering of the highest spin states, as shown in Table 3. Specifically, for both $\mathrm{S} @ \mathrm{Mn}_{12} @ \mathrm{~Np}_{20}$ and $\mathrm{S} @ \mathrm{Mn}_{12} @ \mathrm{Pu}_{20}$ at all three levels of theory employed, the fully Aufbau, highest spin configuration is comfortably the most stable, by 23.72 and $24.64 \mathrm{~kJ} / \mathrm{mol}$ respectively for the neptunium and plutonium systems at the highest level of theory employed (PBE/TZ2P). We are therefore pleased to introduce $\mathrm{S} @ \mathrm{Mn}_{12} @ \mathrm{Pu}_{20}$ as the new record holder for maximum ground state $S$ in a molecular cluster.

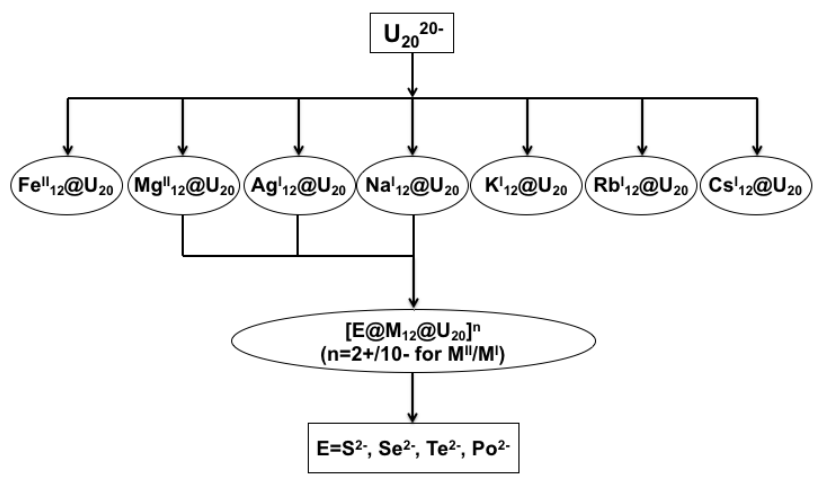

Scheme 1. The $\mathrm{M}_{12} @ \mathrm{U}_{20}$ and $\mathrm{E} @ \mathrm{M}_{12} @ \mathrm{U}_{20}$ nanoclusters reported in this work.

Table 3. Relative energies $(\mathrm{kJ} / \mathrm{mol})$ of the four highest spin electronic configurations of $\mathrm{Mn}_{12} @ \mathrm{An}_{20}$ and $\mathrm{S} @ \mathrm{Mn}_{12} @ \mathrm{An} \mathrm{n}_{20}(\mathrm{An}=\mathrm{Np}, \mathrm{Pu})$, computed with three different functional/basis set combinations

\begin{tabular}{|c|c|c|c|c|c|c|}
\hline & \multicolumn{3}{|c|}{$\mathrm{Mn}_{12} @ \mathrm{~Np}_{20}$} & \multicolumn{3}{|c|}{$\mathrm{S} @ \mathrm{Mn}_{12} @ \mathrm{~Np}_{20}{ }^{\mathrm{a}}$} \\
\hline & VWN/DZ & $\mathrm{PBE} / \mathrm{TZP}$ & $\mathrm{PBE} / \mathrm{TZ2P}$ & VWN/DZ & $\mathrm{PBE} / \mathrm{TZP}$ & $\mathrm{PBE} / \mathrm{TZ2P}$ \\
\hline$S=80 / 2$ & 59.54 & 63.97 & 86.15 & 0.00 & 0.00 & 0.00 \\
\hline$S=78 / 2$ & 0.00 & 82.59 & 57.32 & 45.44 & 36.15 & 23.72 \\
\hline$S=76 / 2$ & 13.56 & 0.00 & 0.00 & 115.52 & 73.72 & 47.32 \\
\hline \multirow[t]{2}{*}{$S=74 / 2$} & 38.58 & 38.66 & 44.60 & 148.62 & 97.40 & 95.77 \\
\hline & \multicolumn{3}{|c|}{$\mathrm{Mn}_{12} @ \mathrm{Pu}_{20}$} & \multicolumn{3}{|c|}{$\mathrm{S} @ \mathrm{Mn}_{12} @ \mathrm{Pu}_{20}{ }^{\mathrm{b}}$} \\
\hline$S=100 / 2$ & 56.27 & 36.15 & 61.67 & 0.00 & 0.00 & 0.00 \\
\hline$S=98 / 2$ & 0.00 & 32.59 & 48.28 & 43.89 & 45.52 & 24.64 \\
\hline$S=96 / 2$ & l & 0.00 & 0.00 & 115.10 & 108.87 & 78.91 \\
\hline$S=94 / 2$ & 40.04 & 58.99 & 52.72 & 182.72 & 166.73 & 131.13 \\
\hline
\end{tabular}


a The electronic occupation is Aufbau for $S=80 / 2$ and $78 / 2$, and non-Aufbau for $S=76 / 2$ and $74 / 2$, with occupied $\beta$ spin orbitals energetically higher than unoccupied $\alpha$ spin orbitals.

${ }^{\mathrm{b}}$ The electronic occupation is Aufbau for $S=100 / 2$, and non-Aufbau for $S=98 / 2,96 / 2$ and $94 / 2$ with occupied $\beta$ spin orbitals energetically higher than unoccupied $\alpha$ spin orbitals.

In summary, systematic DFT investigation has revealed that seven cation cages are stable within an outer $U_{20}$ shell, forming $\mathrm{M}_{12} @ \mathrm{U}_{20}$ nanoclusters $\left(\mathrm{M}=\mathrm{Fe}^{2+}, \mathrm{Mg}^{2+}, \mathrm{Ag}^{+}, \mathrm{Na}^{+}, \mathrm{K}^{+}\right.$, $\mathrm{Rb}^{+}$and $\left.\mathrm{Cs}^{+}\right)$. Three of these systems $\left(\mathrm{M}=\mathrm{Na}^{+}, \mathrm{Mg}^{2+}\right.$ and $\mathrm{Ag}^{+}$) can stabilise a chalcogen dianion at their centre, forming novel Matryoshka actinide nanoclusters E@M $\mathrm{M}_{12} @ \mathrm{U}_{20}(\mathrm{M}=\mathrm{Na}$ and $\mathrm{Mg} ; \mathrm{E}=\mathrm{S}$, Se, Te and Po). Replacement of $\mathrm{M}$ with $\mathrm{Mn}^{2+}$ and $\mathrm{U}_{20}$ with $\mathrm{Np}_{20}$ and $\mathrm{Pu}_{20}$ yields stable nanoclusters with very high spin ground states; $\mathrm{S} @ \mathrm{Mn}_{12} @ \mathrm{Pu}_{20}$ has the highest $S$ value yet reported for a molecular cluster, 100/2. The presence of the central $S^{2-}$ is essential for stabilising the highest spin electronic configurations. Work is underway to establish the origin of the stability afforded by the group 16 dianion. In the meantime, we hope that our calculations will stimulate experimental search for Matryoshka actinide nanoclusters.

\section{Acknowledgements}

We are grateful to the University of Manchester for a postdoctoral research fellowship (to $\mathrm{HSH}$ ) and for computational resources from the University's Computational Shared Facility. We also thank the Environmental Molecular Sciences Laboratory at the Pacific Northwest National Laboratory for a grant of computer time on the CASCADE facility (Proposal Number 49254). HSH is grateful to Dr. Daniel Reta, Dr. Michele Vonci and Dr. Nicholas Chilton for insightful discussions.

Keywords: Actinyl - Matryoshka nanocluster - DFT • High-spin state $\cdot$ peroxide 


\section{COMMUNICATION}

Novel actinide nanoclusters with Matryoshka ("Russian Doll”) geometries have new record high-spin ground states.

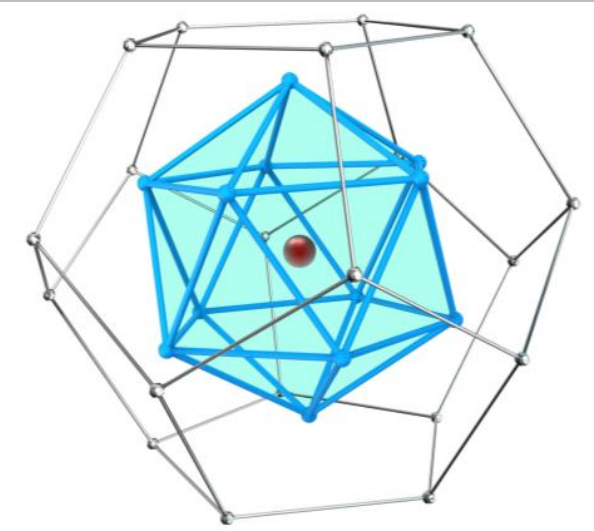

Han-Shi Hu and Nikolas Kaltsoyannis*

Page No. - Page No.

High Spin Ground States in Matryoshka Actinide Nanoclusters: A Computational Study

[1] B. Bechlars, D. M. D'Alessandro, D. M. Jenkins, A. T. lavarone, S. D. Glover, C. P. Kubiak, J. R. Long, Nat. Chem. 2010, 2, 362.

[2] L. Bogani, W. Wernsdorfer, Nat. Mater. 2008, 7, 179.

[3] R. Sessoli, D. Gatteschi, A. Caneschi, M. A. Novak, Nature 1993, 365, 141.

[4] A. K. Powell, S. L. Heath, D. Gatteschi, L. Pardi, R. Sessoli, G. Spina, F. Del Giallo, F. Pierallill, J. Am. Chem. Soc. 1995, 117, 2491.

[5] Z.J. Zhong, H. Seino, Y. Mizobe, M. Hidai, A. Fujishima, S. Ohkoshi, K. Hashimoto, J. Am. Chem. Soc. 2000, 122, 2952.

[6] M. Murugesu, M. Habrych, W. Wernsdorfer, K. A. Abboud, G. Christou, J. Am. Chem. Soc. 2004, 126, 4766.

[7] A. M. Ako, I. J. Hewitt, V. Mereacre, R. Clerac, W. Wernsdorfer, C. E. Anson, A. K. Powell, Angew. Chem. Int. Ed. 2006, 45, 4926.

[8] S. Kang, H. Zheng, T. Liu, K. Hamachi, S. Kanegawa, K. Sugimoto, Y. Shiota, S. Hayami, M. Mito, T. Nakamura, M. Nakano, M. L. Baker, H. Nojiri, K. Yoshizawa, C. Duan, O. Sato, Nat. Commun. 2015, 6, 5955.

[9] G. E. Sigmon, J. Ling, D. K. Unruh, L. Moore-Shay, M. Ward, B. Weaver, P. C. Burns, J. Am. Chem. Soc. 2009, 131, 16648.

[10] G. E. Sigmon, P. C. Burns, J. Am. Chem. Soc. 2011, 133, 9137.

[11] G. E. Sigmon, D. K. Unruh, J. Ling, B. Weaver, M. Ward, L. Pressprich, A. Simonetti, P. C. Burns, Angew. Chem. Int. Ed. 2009, 48, 2737.

[12] J. Qiu, P. C. Burns, Chem. Rev. 2013, 113, 1097.

[13] K. A. Kubatko, K. B. Helean, A. Navrotsky, P. C. Burns, Science, 2003, 302, 1191.

[14] C. R. Armstrong, M. Nyman, T. Shvareva, G. E. Sigmon, P. C. Burns, A. Navrotsky, Proc. Natl. Acad. Sci. USA 2012, 109, 1874

[15] J. Qiu, B. Vlaisavljevich, L. Jouffret, K. Nguyen, J. E.S. Szymanowski, L. Gagliardi, P. C. Burns, Inorg. Chem. 2015, 54, 4445.

[16] M. J. Moses, J. C. Fettinger, B. W. Eichhorn, Science, 2003, 300, 778. [17] Y. Wang, M. Moses-DeBusk, L. Stevens, J. Hu, P. Zavalij, K. Bowen, B. I. Dunlap, E. R. Glaser, B. Eichho, J. Am. Chem. Soc. 2017, 139, 619. [18] S. Stegmaier, T. F. Fassler, J. Am. Chem. Soc. 2011, 133, 19758.

[19] X. Huang, J. Zhao, Y. Su, Z. Chen, R. B. King, Sci. Rep. 2014, 4, 6915. 